\title{
The Methodology of Qur'anic Message in The Website (Case Study on https://muslim.or.id/)
}

\author{
$1^{\text {st }}$ Millah Maryam As-Sa'idah ${ }^{1}, 2^{\text {nd }}$ Izzah Faizah Siti Rusydati Khaerani ${ }^{1}, 3^{\text {rd }}$ Ahmad \\ Izzan $^{1}, 4^{\text {th }}$ Nabilah Nurainy ${ }^{1}$ \\ \{millahmarymassaidah@gmail.com¹, izzahfaizahsiti@uinsgd.ac.id ${ }^{1}$,izzan_2008@yahoo.com¹ \\ glowdaysoabil@gmail.com¹
}

UIN Sunan Gunung Djati Bandung, West Java, Indonesia ${ }^{1}$

\begin{abstract}
Technological developments have affected every activity of people around the world, including Muslim communities in Indonesia who are beginning to use technology to spread Islamic teachings. The interpretation of the Qur'an have long utilized their increasingly sophisticated technology, by using electronic, media as a tool to spread Quranic interpretation. In this case, websites have became a form of online media that can be used to spread Qur'anic interpretation. This study aims to analyze the sources, methods, and patterns of the Qur'anic interpretation on websites, specifically in http://muslim.or.id. This research uses qualitative research method through literature study by using the descriptive-analytical method. The results of this study reveal the source of the Quranic interpretation on http//:muslim.or.id website is bi al-ma'thūr and $b i$ $a l-r a ' y i$. In addition, this website uses two methods of Qur'anic interpretation, namely maudu'i and muqaran. This inconsistency methods is due to the number of authors contribute to the articles posted on the website. The main characteristic of the website's Qur'nic interpretation is ijtima'i because it published articles on the interpretation of trending themes or issues as its answers to problems facing Muslim communities in Indonesia.
\end{abstract}

Keywords: component; formatting; style; styling; insert (key words)

\section{Introduction}

In the last 20 years, technology has been developing and influencing various activities of people around the world. Due to this development, information can be accessed more easily than before [1]. Online media become alternative tools to meet the increasingly complex human needs, including spiritual needs of religious understanding [2]. We have seen Indonesian Muslim communities looking for answers or solutions to their personal problems by visiting online media. Currently, online media are used by users as tools to post articles about Islam such as about about figh, muamalah, morality, 'aqidah, hadith and Qur'anic interpretation.

Various Muslim groups use online media as facilities to post articles on Quranic interpretation. Previously, the study of Quranic interpretation was conducted through e-book version of the works on Qur'anic interpretation which can be accessed from applications like Maktabat al-Shämilah. Social networking media such as Facebook, Twitter, Instagram, and Whatsapp, are also used to spread studies on Qur'anic interpretation [3]. Currently, website is 
a form of online media that play an important role inthe dissemination of Qur'an interpretation. This medium can be accessed more easily and faster than other media. According to Andrey Andoko,in order to reach 60 million people, while radio requires 30 years and television requires 15 years, website only needs 3 years.[4] This paper focuses its investigation on a website, http//:muslim.or.id with some reasons. First, http//:muslim.or.id is an official website that can be used as a source of reference for academics; second, it has a well organizedmanagerial structure; third, it has been visited by 5.8 billion viewers in January 2008; and fourth, on October 2015, it earned the 4th place in Alexa for the keywords "Indonesian", "society”, 'religion', and "Islam".

This paper aims to analyze the sources, methods, and styles ofthe articles on interpretation of the Qur'an posted in http//:muslim.or.id. The method used is library research. In this case,literature on the methodology of interpretation is described and analyzed critically.

\section{Discussion}

\subsection{Tafseer and Interpretation}

Tafseer is the highest science position, it is a science that is needed because the object of discussion is the Qur'an which became the source of Muslim life. People who serve God, seek the pleasure of God and obey God by carrying out the demands of God contained in the Qur'an. Therefore the Muslim must understand the content of Quranic verses properly and correctly [5]. The word "interpretation" is derived from the word "fassara-yufassiru means interpretation". While the term by Abu Hayyan is the science which deals with the pronunciation of word (lafad) Qur'an, concerning directives, laws either as a stand-alone or as composed and meanings that make it up [3]. Meanwhile, according to Al-Zarkashi tafsir is a knowledge that with that knowledge can understand the Quranic verses that are revealed to the Prophet Muhammad, by explaining the intentions, issuing laws and wisdom [6].

In accordance with some interpretations that have been expressed, then the study of Quranic interpretation contained in the website Muslim.or.id is a form of interpretation of the Qur'an. Because the authors of the article Muslim.or.id is trying to explain the Quranic verses that became the discussion of each author though by quoting from some mufasir.

Paragraphs interpreted in the website Muslim.or.id are the required verses according to the theme raised by the article authors on the website. So not all Quranic verses are interpreted by the authors. Each author always providesthe source or reference they use, be it in the form of footnotes or bibliography. There are approximately sixty-eight themes that have been written by the authors of the article with mentoning several verses used for each of them.

There are five ways to explain an article theme:

1) Interpreting the Quranic verses with their own thoughts. For example, a discussion of people always associates the number of verses with the date of the occurrence of volcanic eruptions. This discussion is explained in accordance with author ${ }^{\text {ee }}$ sideas [7].

2) Explaining the interpretation of the results of the review that the author of the article had heard earlier. An example of this form is a discussion of the interpretation of the surah AlBaqara [2]: 264 which the author of the article listened to Zaid Susanto who had lectured at ma'had Jamilul Rahman Bantul, Yogyakarta. Zaid him self uses the book of Nidā-a AlRaḥman li Ahli Al-Īmān.

3) Interpreting the verse using the opinions of the mufasir. An example of this form is the interpretation of surah Al- Baqara[2]: 256 which explains the absence of compulsion in 
religion. In explaining the interpretation the author of the article uses the opinion of Al-Țabari, Abū Hāatim, Al-Shaukani,'Ali Al-Șabuni, Ibn Kathīr and Al-Qurț̄ibi [8].

4) Summarizing from an Arabic book (not a book of tafseer). An example of this form is the discussion of the degree of people who are studying. In this theme has included the verses namely; Surah of Al- Mujadalah [58]:11, Al-Anfāl [8]: 2-4, Țaha [20]: 75 and Al-Nisā [4]: 95-96. This interpretation uses the source of Fadl Al-'Ilmi wa Adabu Talabatihi wa Turuqu Tahsilihi wa Jami'hi by Shaykh Muhammad bin Sa'id bin Ruslan.[9]

5) Interpretation of the results of the translation of interpretation studies on foreign Arabic-speaking websites. The example of the article is "Wisdom of creating Heaven and Earth for 6 Days".[10]

\subsection{Various Types of Tafseer}

The interpretation of bi al- ma'thūr is divided into two groups; valid bi al-ma'thür and invalid bi al-ma'thür tafsir. The interpretation of valid bi al-ma'thür is the interpretation of the Qur'an based on the narration of sanad and matan that can be accounted for by the science of hadith [11]. While the interpretation of invalid bi al-ma'thūris the interpretation of the Qur'an based on an incorrecthistory [12].

The interpretation of bi al-ra'yi is the interpretation of the Qur'an that results from the ijtihad of a mufassir who knows the Arabic and his knowledge, the jahiliyah poems, asbab alnuzul, nasikh mansukh and other science required by a mufasir.[13] Although there are some scholars who oppose commentary using reason and some are permissible,Husein al-Dhahabi tried to find a middle ground. According to him the interpretation of the Qur'an can be done by both bi al- ma"thur and bi al-ra'yi. But otherwise if not according to the rules of the Arabic and Quranic arguments also hadith then it is forbidden.[14] The sources used by the website Muslim.or.id are bi al-ma'thūr and bi al-ra'yi. According to 'Ali Al-Șabuni such an approach is called Tafsìr lì Alquran Al-Karìm Jami' baina Al-Ma'thūrwa Al-Ma'qūl.[15] Examples of interpretation of the Qur'an in the website Muslim.or.id derived from the interpretation of $b i$ al-ma'thūr using the Qur'an; Interpretation of Al-'Ankabūt's: 3:

"We did test those before them, and Allah certainly know those who are true from those who are false."

The above verse is interpreted using Al-Taubah: 115, Āli 'Imran: 119 and 29. The article discusses this entitled "Tafsir Ayat" That Allah Know the Honest and the Lies.[16] According to the authors of the article that God knows all that is in the heavens and on earth and Allah always knows what His servants hide. In addition, to complete the interpretation, the author of the article also uses Al-Baqara: 143 to explain Al- 'Ankabüt: 3.Referring to hadith of the Prophet also used bu the author in some interpretation. For example the interpretation of AlBaqarah:273, "... the ignorant thinks, because of their modesty, that they are free from want.." Explanation of the word"ta'affuf" the author of the article using the hadith of the Prophet:"Whosoever behaves' iffah (keep the honor of self) Allah will keephis purity" [HasanShahih HR. Al-Nasa 'i] [17].

The evidence of bi al-ra'yi's interpretation in the Muslim.or.id website is visible from some of the authors who write the articles, they are using or quoting a book of exegesis as their sources from tafsir categorized as bi al ra'yu like rūh al-ma'añ of al-Alūsī . For example ininterpretating Al-Anbiya:27 in an article entitled "Islam Rahmatan Lil'alamiin", written by Yulian Purnama. In explaining this verse the author quotes Al-Ṣabunī as follows: "The meaning of this verse is" It is not We send you, O Muhammad, but as a mercy to all beings ". As in a hadis "Verily I am a mercy granted (by Allah)" (HR. Bukhari). 


\subsection{Based on Method}

There are four acknowledged methods of interpretation, namely: tahlili,ijmali, muqaran and maudlu'i. Muslim or.id using two method, muqran method and maudhui method.

The steps of muqaran method that a mufassir needs to follow are as follows: [18]

1. Similarverses with different case, as follow:

a. Searching and collecting the intended verses. Then, comparing and reviewing in accordance with the rules of interpretation to take a conclusion

2. Comparing Quranic verseswith any contradictory hadith:

a. Collecting the Qur'anic verses and matan hadith inquestion.

b. Comparing sufficiently and take a conclusion after going through theanalysis.

3. Comparing the interpretation of anulamato other interpretations of the sameissuewith several stepslike:

a. Give attention to a number of verses that discuss the issue to be discussed.

b. Trace the opinions of the mufassirinon theissue.

c. Examine similarities and differences of suchinterpretation

The maudu'i method explain verses of the Qurean according to certain themes. Then the verses are analyzed and understood by paying attention to amm and khas,(general to specific), mutlaq and muqayyad and others. The explanation isenriched with the hadiths related to the theme and then take the conclusion [19].

Al-Farmawi divided the maudu'i method into two forms namely; First, a discussion of the full and complete interpretation of a surahin the Qur'an, explaining its general and specific intent(wahdahmawdluiyyah fi surah). Explain the relationship between the various problems in the surahcarefully [20]. Second, collect a number of verses from various surahthat also address one particular problem, then arrange them in theme and then interpreted thematicly [21]. From the above explanation, and after analising the website of Muslim.or.id, we found out that the method used is maudu'i and muqaran. The argument for the existence of these two methods is because many of the authors who write articles in this website are inconsistency in use of both methods.Besides, each author hasits own way of compiling and reviewing his interpretation.

The facts on the ground that not all articles of interpretation in this website are following the steps as explain before, although some are fall into the category of methods that have beenpresented.

Example of the interpretation using mawdlu'i method is Surah Al- Zalzalah with entitled a devastating earthquake on the Day of Resurrection". This interpretation follow the steps explain in mawdlue' I method.

The next interpretive method is muqaran. We found muqaran method in the website Muslim.or.id,in two forms namely; (1) describing the verses in which the editorial is different but speaks of the same issue and (2) comparing the interpretation of the verse from the interpreters' opinions on the verse inquestion.

The example article using the muqaran method is the interpretation of Al-Anbiya:70, where the authors compare Ibn al-Qayyim al-Jauziyah's commentary on Ibn al-Qayyīm, AlShaukani in the book of Faț Al-Qadir, Al-Tabari in the book of Tafsir Al-Tabarī,Al-Qurțībi in TafsirAl-Qurțūbī, 'Alī Al-Șabunī in the book Șafwah Al- Tafsīr after.. The next article is about the prohibition of the Muslims making the unbelievers as auliya. The author of the article listed several verses that have the sametheme: Ali „Imran [3]: 28, Al-Māidah [5]:51, AlMāidah [5]:57, Al-Taubah [9]:23, Al-Mumtahanah [60]:1, Al-Nisā [4]:89, Al-Nisā [4]:139,AlNisā[4]:144and suratAl-Māidah[5]: 81.34 


\subsection{Based on Style}

The style is a feature or characteristics coloring interpretation of the Qur"an. A mufassir explains Quranic verses with his abilities and describes his interest and horizontal knowledge. Therefore, a book of tafsir produced has a style that is in accordance with the disciplines that mufassir has. Among the famous tafsir styles are;

Firts, Tafsir Sufi is a style of interpretation of Tasawwuf which usually adopedishari approach [22].

Second, jurisprudence interpretation is a dominant style of interpretation of the Qur'an to discuss the issue of fiqh [23]. Tafseer Jurisprudence is more oriented to the verses of the law in the Qur'an then to other isuue.37Al- dhahabi in his book explains that the juristic interpretation always talks about the verses about the law, and always discusses the madhhabmadhhabor schools of jurisprudence with their respective arguments [24].

Third, Falsafi interpretation is the interpretation of the Qur'an based on a logical approach or philosophical thought that is liberal and radical. The philosophical interpretations attempt to combine philosophy and religion [25].

Fourth,interpretation of ilmi style is the interpretation of the more focused discussion with the approach of general sciences.41This interpretation strives to bear different branches of science and involves philosophical thought [26].

Fifth, adabi ijtima'i. tafsir which emphasizes the discussion taking consideration to social problems [27]. According to Muhammad Husain Al-Dzahabi, the pattern adab iijtima'i able to express the terms of balaghah Alquran and miracles, explaining the meanings and targets directed by the Qur'an, revealing the great laws of nature and order the society it contains. This style aims at paying attention o solve the problems of Muslims and other human beings, put forward the guidance of the Qur'an and its teachings. Further,it can give the happiness of the world and the hereafter by integrating the Quran and the correct scientific theories.This style shows that the Qur'an is an eternal and able to compete with the times, and reject the vagueness, misgivings and false allegations of the Qur'an [28].

The pattern used by the website Muslim.or.id is categorized asijtima'I, without adaby.The reason is based on many interpretation refer more to social aspect faced in contemporary era than to Arabic and literary meaning. Examples of articles are about the veil [29].

\section{Conclusion}

The study of Qur'anic commentary on websites is relatively a new field of study. The above analysis of Qur'anic interpretation of http//:muslim.or.id shows that the website adopts a simple and understandable ways of Qur'anic interpretation, which are accessible by ordinary Muslims. The interpretation of the Qur'an in the website takes a form of excerpts taken from classic and modern mufassir. The writers of posted article directly refer to the original sources of Qur'anic interpretation literature.

Therefore, http//:muslim.or.id is a website that can be taken a source or reference by Muslims and non-Muslims who need to understand the Qur" an. It can also be used as a reference by common people for daily needs or by students for academic purposes

\section{References}


[1] Muhamad Rifefan, "Penggunaan Media Online Dalam MemenuhiKebutuhan Informasi Akademis (Studi Deskriptif Kualitatif Pada Kalangan Mahasiswa Universitas Negeri di Yogyakarta)" (Skripsi Program Sarjana, Universitas Islam NegeriSunanKalijaga Yogyakarta, 2014),1.

[2] Ginanjar Akbar, "Metode Pembelajaran Alquran Melalui Media Online," IJNS 2, no. 1 (2013): 65

[3] Nafisatuzzahro", "TafsirAlquran AudioVisual Di Cyber Media: Kajian Terhadap Tafsir AlQur'an Di YouTube Dan Implikasinya Terhadap Studi Al- Qur " an Dan Tafsir" (Tesis program Pascasarjana Universitas Islam Negeri Sunan Kalijaga Yogyakarta, 2016),7.

[4] Freddy H Istanto, "Potensi Dan Kaidah Perancangan Situs-WEB Sebagai Media Komunikasi Visual," Nirmana 3, no. 1 (2001): 52

[5] Ahmad Von Denffer, Ilmu Al-Qur'an:Pengenalan Dasar, trans. Ahmad Nashir Budiman, "Ulum Al-Quran : An Introduction to the Sciences of the Quran", (Jakarta: Rajawali, 1988), 142

[6] Mashuri Sirojuddin Iqbal dan A. Fudlali, Pengantar Ilmu Tafsir, (Bandung: Angkasa, 2005), 86.

[7] Muhammad Abduh Tuasikal, "Mengaitkan Gunung Meletus Dengan Nomor AyatAlQur'an”, 2014, diakses pada tanggal 10 Mei 2018

[8] Yulian Purnama, “Tafsir Ayat „Lāikrāha fi al-dīn”, 2010, diakses pada tanggal 08 Mei 2018, https://muslim.or.id/1851-tafsir-ayat-laa-ikraha-fiddiin.html

[9] Adika Mianoki, Derajat Mulia Penuntut Ilmu Agama”, 2017,diakses pada tanggal 10 Mei2018, https://muslim.or.id/29242-derajat-mulia-penuntut- ilmu-agama-2.html

[10] YulianPurnama, "Hikmah Diciptakannya Langit dan Bumi Selama 6, Hari”, 2012, diaksespadatanggal 08 Mei 2018, https://muslim.or.id/10827-hikmah-diciptakannya-langit-dan-bumiselama-6-hari.htm

[11] Ahmad Izzan. Metodologi IlmuTafsir, (Bandung: Tafakur, 2014), 69

[12] Ahmad Izzan. Metodologi IlmuTafsir, (Bandung: Tafakur, 2014), 69

[13] Al-Dhahabi, Ensiklopedia Tafsir ,240.

[14] Al-Dhahabi, EnsiklopediaTafsir ,248

[15] Abdul Malik, Al-Munir, "Metode dan Corak Penafsiran Syeikh Muhammad „Ali As-Shābūni (Analisis Terhadap Tafsir Safwat Al-Tafsir)", (Skripsi Program Sarjana Universitas Islam Negeri Sultan Syarif Kasim Riau, 2013), 53

[16] Yulian Purnama, "Tafsir Ayat "Agar Allah Mengetahui Orang yang Jujur dan Orang yang Dusta", 2015, diaksespadatanggal 16 Maret 2018, muslim.or.id/25789-tafsir-ayat-agar-allahmengetahui-orang-yang-jujur-dan-yang-dusta.html.

[17] Muhammad NurIchwan Muslim, "Selektif dalam Berinfak", 2011, diakses pada tanggal 06 Mei 2018, https://muslim.or.id/5608-selektif-dalam-berinfak.html.

[18] Izzan, Metodologi Ilmu Tafsir, 113. Quraish Shihab, .Kaidah Tafsir, Tangerang: Lentera hati, 2015 ,

[19] Al-Farmawi, Metode Tafsir Madhu'iy :Sebuah Pengantar, 35.

[20] Al-Farmawi, Metode Tafsir Madhu'iy: Sebuah Pengantar, 36.

[21] Acep Hermawan, 'Ulumul Quran,(Bandung: Remaja Rosdakarya, 2016),132.

[22] Hermawan, 'Ulumul Quran, 132.

[23] Acep Hermawan, 'Ulumul Quran,(Bandung: Remaja Rosdakarya, 2016),132

[24] Adz-Dzahabi, EnsiklopediaTafsir ,335

[25] Badri Khaeruman, Sejaran Perkembangan Tafsir Alquran, (Bandung: Pustaka Setia, 2004), 17 dan Ahmad Izzan, Ulumul Qur'an

[26] Izzan, Metodologi Ilmu Tafsir, 201

[27] Acep Hermawan, 'Ulumul Quran,(Bandung: Remaja Rosdakarya, 2016),132.

[28] Al-,Aridl, Sejarah Dan MetodologiTafsir, trans. Ahmad Akrom “Tarikh „Ilm AlTafsirwaManahij Al- Mufassirin”, 71. 
[29] Purnama“Ayat Alquran tentang Cadar", 2018, diakses pada tanggal 03 Mei 2018, https://muslim.or.id/37208-ayat-al-quran-tentang- cadar.html. New York: Chapman \& Hall/CRC, 2007. 